\title{
"BUT OF COURSE THE STAGE HAS CERTAIN LIMITS"? THE ADAPTATION OF OVID'S METAMORPHOSES IN SHAKESPEARE'S PLAYS
}

\begin{abstract}
Stage adaptations of the physical transformations as evoked in Ovid's Metamorphoses have been deemed impossible or at least deficient in literary criticism, in particular with regard to Shakespeare's plays. My paper critically engages with this assessment and explores the ways in which metamorphoses can be staged in the theatre. Focusing on moments of transformation in Titus Andronicus, The Winter's Tale and A Midsummer Night's Dream, it examines actual theatrical realisations of different epochs as well as staging options of the scenes and argues that critics examining Shakespeare's metamorphoses have tended to neglect the mobility and polyfunctionality of theatrical semiosis in favour of an implicitly verisimilar notion of theatrical representation. Rather than exclusively aspiring to a verisimilar staging of bodily metamorphosis, the scenes self-reflexively comment on the double vision of theatre audiences, who witness both the intradiegetic moments of shape shifting and the incessant metamorphoses of theatrical signs, including the bodies of actors, which constitute and distinguish theatre as an art form.
\end{abstract}

Francis Meres in his 1598 study A Comparative Discourse of Our English Poets with the Greeke, Latine, and Italian Poets programmatically declared the thematic and stylistic closeness of Ovid and Shakespeare: "the sweete wittie soule of Ovid lives in mellifluous and honey-tongued Shakespeare". 1 Ever since then, academic research has demonstrated the manifold references in Shakespeare's plays to both the fifteen books of the Latin original, the Metamorphoseon Libri, and to Arthur Golding's free English translation. ${ }^{2}$ Ovid's Metamorphoses are so crucial for Shakespeare's mythic references that Robert Kilburn Root's study Classical Mythology in Shakespeare states,

\footnotetext{
${ }^{1}$ Qtd in Jonathan Bate, Shakespeare and Ovid (Oxford: Clarendon, 1993) 2.

${ }^{2}$ Due to its many changes to the original, Golding's translation might better be regarded as an adaptation itself. As Bate and others have shown, Shakespeare's choice of vocabulary proves that he referred both to the Latin original and to Golding's version. Bate 1993, 8. For a discussion of the differences between Golding's translation and the moralising versions by George Sandys and William Caxton, in which "[a] Christian tradition of interpreting stories inevitably conflicted with a 'humanist' interest in studying texts", see Raphael Lyne, "Ovid in English Translation", The Cambridge Companion to Ovid, ed. Philip Hardie (Cambridge: Cambridge UP, 2002a) 249-63, at 251.
} 
"the whole character of Shakespeare's mythology is essentially Ovidian."3 In his dramatic adaptation of the Metamorphoses, Shakespeare revises the canonical stories in several respects: Rather than depicting the teleological, irreversible and physical transformations narrated by Ovid, Shakespeare frequently presents metaphoric and psychic transformations, which are, moreover, sometimes reversible. ${ }^{4}$ Further, Shakespeare on occasion employs only parts of the stories: Whereas he deprives his tragic characters of the final redeeming transformation, in the comedies he saves potential victims from an impending violation. ${ }^{5}$ Hence, he transforms Ovid's transformation stories according to the dramatic genre conventions which require or foreclose a happy ending. Apart from these innerfictional changes, the Shakespearean adaptation of Ovid's stories of course also involves a genre transfer from narrative poetry to drama as well as a medium change from written literature to theatre, and hence, in the taxonomy proposed by modern narratology, from

${ }^{3}$ Robert Kilburn Root, Classical Mythology in Shakespeare (New York: Holt, 1903) 3. This regard for Ovid and the concentration on the Metamorphoses rather than on the Ars Amatoria was, as Laurence Lerner emphasises, characteristic of Shakespeare's day: "The Ovid who mattered most to the sixteenth century was not the love-poet but the mythographer, and the Metamorphoses is both his most important and his most influential poem". Laurence Lerner, "Ovid and the Elizabethans", Ovid Renewed: Ovidian Influences on Literature and Art from the Middle Ages to the Twentieth Century, ed. Charles Martindale (Cambridge: Cambridge UP, 1988) 121-36, at 126.

${ }^{4}$ See Manfred Pfister, “'What's Hecuba to him?' Vom Nutzen und Nachteil mythischer Geschichten für Shakespeare”, Shakespeare Jahrbuch: Shakespeare als Erzäbler von Märchen und Mythen, ed. Ina Schabert et al. (Bochum: Kamp, 2006) 13-33; Bate 1993, 28 and passim; the sixth chapter of Leonard Barkan, The Gods Made Flesh (New Haven and London: Yale UP, 1986); Ovid Renewed: Ovidian Influences on Literature and Art from the Middle Ages to the Twentieth Century, ed. Charles Martindale (Cambridge: Cambridge UP, 1988); Elisabeth Truax, Metamorphosis in Shakespeare's Plays: A Pageant of Heroes, Gods, Maids and Monsters (Lewiston etc: Edwin Mellen Press, 1992); Shakespeare's Ovid: The Metamorphoses in the Plays and Poems, ed. A.B. Taylor (Cambridge: Cambridge UP, 2000); The Cambridge Companion to Ovid, ed. Philip Hardie (Cambridge: Cambridge UP, 2002a). Shakespeare's adoption of Ovid's metamorphoses as metaphors can be understood as a recirculation if we follow Sarah Ann Brown's definition of Ovid's metamorphoses as conceits, as metaphors made flesh. Sarah Ann Brown, The Metamorphosis of Ovid: From Chaucer to Ted Hughes (London: Duckworth, 1999) 2.

${ }^{5}$ Bate 1993, 119. The mythological content of the source notwithstanding, Shakespeare of course also undertook changes that were characteristic of the stage adaptation of prose texts in general. For example, he changed the dramatis personae and settings, shortened the depicted time span and modified the characterisation and motivation of figures. See Max Bluestone, From Story to Stage: The Dramatic Adaptation of Prose Fiction in the Period of Shakespeare and His Contemporaries (The Hague and Paris: Mouton, 1974) 19. 
a temporal, linguistic one-channel medium to a spatio-temporal, linguisticacoustic-visual-olfactory multiple-channel medium. ${ }^{6}$

Regarding this transgeneric and transmedial shift, the adaptation of moments of corporeal change in Ovid's Metamorphoses for the stage in general and in Shakespeare's plays in particular has been deemed impossible or at least deficient in literary criticism. For example, Jonathan Bate emphasises in his seminal study Shakespeare and Ovid that "of course the stage has certain limits" when it comes to physical shape shifting. ${ }^{7}$ Colin Burrow agrees in his contribution to The Cambridge Companion to Ovid that literary texts are better suited than the stage to depict metamorphosis: "Ovidian experiments ... were possible on the page, but on the Elizabethan stage there were clearer limits to what could and could not be done with bodies. ... It is ... impossible onstage to metamorphose an actor into an animal or plant". ${ }^{8}$ Friedmann Harzer's monograph on narrated metamorphosis even argues that principally only narrative prose and poetry can provide the 'depiction of the non-depictable of metamorphosis': ${ }^{9}$

The poetics of metamorphosis is a poetics of narrated shape shifting, since the process cannot be represented in the theatre without becoming a masquerade or a freeze image. Only the development of film offers an ostensibly adequate medium that can compete with narrated metamorphoses, but film images restrict the scope of imagined metamorphoses. ${ }^{10}$

Since narration is always concerned with the progress of action and with the change of situations, Harzer posits, a narrated metamorphosis epitomises the arch-principle of narration and hence has metapoetic potential. Scenes of staged metamorphosis likewise, I shall argue, tend to have metatheatrical relevance. This is partly due to the fact that the principles of proceeding action and situation/setting change apply to drama just as well; they have

\footnotetext{
${ }^{6}$ Marie-Laure Ryan, “Introduction”, Narrative Across Media: The Languages of Story-Telling, ed. Marie-Laure Ryan (Lincoln: U of Nebraska P, 2004) 1-40, at 21 and passim. For an analysis of the generic differences and similarities of dramatic and narrative texts, see also Holger Korthals, Zwischen Drama und Erzählung: Ein Beitrag zur Theorie geschehensdarstellender Literatur (Berlin: Schmidt, 2003) esp. 27-52.

${ }^{7}$ Bate 1993, 143.

${ }^{8}$ Colin Burrow, "Re-embodying Ovid: Renaissance Afterlives", The Cambridge Companion to Ovid, ed. Philip Hardie (Cambridge: Cambridge UP, 2002a) 30119 , at 306.

${ }^{9}$ Friedmann Harzer, Erzählte Verwandlung: Eine Poetik epischer Metamorphosen (Ovid - Kafka - Ransmayr) (Tübingen: Niemeyer, 2000) 140.

${ }^{10}$ Harzer 2000, 46. My translation of: "Die Poetik der Metamorphose ist wesentlich eine Poetik erzählter Verwandlung, weil der Vorgang einer Metamorphose auf dem Theater nicht zu repräsentieren ist, ohne zur Maskerade zu werden oder zum StandBild zu erstarren. Erst die Entwicklung des Films schafft ein scheinbar adäquates Konkurrenzmedium für erzählte Verwandlungen, doch auch filmische Bild-Texte engen den Spielraum imaginierter Verwandlung ein.”
} 
indeed also been considered drama's primary principle ever since Aristotle's Poetics. ${ }^{11}$ Yet on the Elizabethan stage the rapid change of situations and settings was even more fundamental than in ancient drama, since most plays did actually transcend the model of the Aristotelian unity of time and space. To stage these rapid changes, theatre practitioners had to make extensive use of the polyfunctionality and mobility of theatrical signs. In this respect, as I shall elaborate below, the metatheatrical potential of staged metamorphoses also touches upon the characteristics of theatrical semiosis itself, which relies profoundly on the transformations of theatrical signs.

Taking issue with the pessimistic academic assessment of theatrical metamorphoses in literary criticism, this essay will explore ways in which bodily change can be staged in the theatre. Since Shakespeare's adaptations of Ovid's Metamorphoses have attracted the greatest amount of critical attention and provide a wealth of material regarding the issue of genre and medium change, the following pages will focus on three exemplary moments of shape shifting in Shakespeare's dramatic oeuvre. As I attempt to show with respect to Titus Andronicus, The Winter's Tale and A Midsummer Night's Dream, the highly mobile, polyfunctional theatrical semiosis provides ingenious solutions for the challenge of adapting narrated metamorphoses. I will consider the selected scenes of bodily transformation with a view to their performance options, thus paying tribute to the two, interdependent sign systems of drama and theatre. Since the composition and validity of the multiple-channel performance text depends on conventions that are historically and culturally variable, the examination of stage productions of both Shakespeare's day and later epochs will facilitate the discussion of general theatrical possibilities for presenting corporeal change on stage.

Ovid's texts appear to lend themselves to dramatic adaptation, since they - in contrast to many prose texts adapted for Elizabethan plays ${ }^{12}$ - focus on dynamic action rather than static description. They nonetheless provide ample detail regarding the outward looks and behaviour of characters, and some passages consequently read almost like comprehensive stage directions.

${ }^{11}$ Aristotle asserts the primacy of plot for tragedy: "the incident and the plot are the ends at which tragedy aims, and in everything the end aimed at is of prime importance. Moreover, you could not have a tragedy without action, but you can have one without character-study. The plot then is the first principle and as it were the soul of tragedy". Aristotle: The Poetics. "Longinus": On the Sublime. Demetrius: On style, ed. William H. Fyfe (London: Heinemann 1953) 24-27, VI. 7-20.

${ }^{12}$ Cf. Bluestone's criticism of the prose fiction adapted in Elizabethan drama: "The prose fiction adapted in Elizabethan plays ... cannot provide a credible imitation of change ... . [I]ts past tense freezes events in static verbal reports. ... Prose fiction chiefly recapitulates events and resides in stasis. Drama represents changing events directly and generates the continuous movement of an active present". Bluestone $1974,169$. 
This "poetics of specularity", ${ }^{13}$ as well as the frequent use of direct speech, makes the Metamorphoses particularly suitable for the theatre. For example, Ovid continues after the long farewell speech by Pandion, Philomela's father:

Mandabat pariterque suae dabat oscula natae, et lacrimae mites inter mandata cadebant; utque fide pignus dectras utriusque poposcit inter seque datas iunxit natamque nepotemque absentes pro se memori rogta ore salutent supremumque vale pleno singultibus pore vix dixit timuitque suae praesagia mentis. ${ }^{14}$

Golding's English version preserves the dynamic manner of Ovid's description:

In giving charge, he kissed hir; and downe his cheekes did raine The tender teares, and as a pledge of faith he tooke the right Handes of them both, and joyning them did eche to other plight, Desiring them to beare in minde his commendations to His daughter and hir little sonne. And then, with much adoe For sobbing, at the last he bad adew as one dismaid; The foremisgiving of his minde did make him sore afraid. ${ }^{15}$

Such sections invite dramatisation, since they not only provide cues for the psychic state and motivation of the figures, but also describe the facial expression, gestures and non-linguistic utterances in a precise manner.

On the other hand, the transformations described by Ovid are so supernatural that they pose a challenge for every stage realisation. When the tragedy of Titus Andronicus presents Lavinia's mutilation and the subsequent description of her body as metamorphoses, when the romance The Winter's Tale animates Hermione's statue, and when the comedy A Midsummer Night's Dream transforms Bottom into an ass, theatre practitioners have to find a theatrical equivalent to the metamorphosis as portrayed in the narrative source. Attempting to stage the metamorphoses, theatre practitioners encounter a task which Murray Krieger has termed, with regard to pictures, reverse ekphrasis, that is, the creation of a picture based on its linguistic description. ${ }^{16}$ The issue of reverse ekphrasis concerns the poeto-

${ }^{13}$ Gianpiero Rosati, Narciso e Pigmalione: Illusione e spettacolo nelle Metamorfosi di Ovidio (Firenze: Sansoni, 1983) 152, qtd in Philip Hardie, Ovid's Poetics of Illusion (Cambridge: Cambridge UP, 2002b) 173.

${ }^{14}$ Ovid, Metamorphosen: Tusculum Studienausgabe Lateinisch-Deutsch, ed. and trans. Gerhard Fink (Düsseldorf/Zürich: Artemis und Winkler, 2003) 218.

15 Arthur Golding, Ovid's Metamorphoses: A Selection, ed. Peter Scupham (Manchester: Fyfield Books, 2005) 45-46, 11. 645-51.

${ }^{16}$ Murray Krieger, Ekphrasis: The Illusion of the Natural Sign (Baltimore and London: Johns Hopkins UP, 1992) xiii. See also Hardie 2002b, 177-78 on 
logical differentiation of art forms, which has been controversial ever since antiquity and which fed a lively cultural debate during Shakespeare's time. ${ }^{17}$ For example, in The Defense of Poesy (1595), Philip Sidney compares painting and literary writing. In unison with his ancient forerunners Simonides of Chios and Horace, ${ }^{18}$ he posits that poetry as a "speaking Picture", ${ }^{19}$ just like painting, can offer a (moral) vision which even excels reality. Sidney proposes dividing poets, like painters, into three categories and argues that only the best poets are able to offer more than the verisimilar reproduction of their subject matter: "who having no law but wit, bestow that in colours upon you, which is fittest for the eye to see" ${ }^{20}$ The third, the best group of painters and poets "be they which most properly do imitate to teach delight: and to imitate, borrow nothing of what is, hath bin, or shall be, but range only reined with learned discretion, into the divine consideration of what may be and should be." ${ }^{21}$ Sidney here connects the pervasive early modern "[f]ascination with the idea of illusionist representation" and "compulsion for a 'rhetoric of presence" 22 with an Aristotelian notion of the ethical power of mimesis, since he portrays both painters and poets as moral visionaries whose works of art excel the mere representation of reality by providing deeper insights. ${ }^{23}$ To convey profound meanings beyond

Ovid's “ekphrastic universes" and Mario Klarer, Ekphrasis: Bildbeschreibung als Repräsentationstheorie bei Spenser, Sidney, Lyly und Shakespeare (Tübingen: Niemeyer, 2001) 138-81 on ekphrasis in Shakespeare's plays.

${ }^{17}$ See Jean H. Hagstrum for a tracing of the comparison of arts from Simonides of Chios's "Poema pictura loquens, pictura poema silens" to Horace's phrase "ut pictora poesis" and its first publication in England in Hoby's translation of Coignet's Politique Discourses (1586): "Painting is dumme Poesie, and a Poesie is a speaking picture; \& the actions which the Painters set out with visible colours and figures the Poets recken with wordes, as though they had in deede been perfourmed". Qtd. in Jean H. Hagstrum, The Sister Arts: The Tradition of Literary Pictorialism and English Poetry from Dryden to Gray (Chicago: U of Chicago P, 1958) 58.

${ }_{18}$ Christopher Braider illuminates which "creative misprision" was involved in the reception of Horace that led to the Renaissance notion of ut pictorapoesis. Christopher Braider, "The Paradoxical Sisterhood: 'ut pictura poesis"” The Cambridge History of Literary Criticism, Vol. 3: The Renaissance, ed. Glyn P. Norton (Cambridge: Cambridge UP, 1999) 168-98, at 170.

${ }^{19}$ Philip Sidney, The Defence of Poesie, ed. Wolfgang Clemen (Heidelberg: Winter, 1950) 11 (emphasis in the original).

${ }^{20}$ Sidney 1950, 12.

${ }^{21}$ Sidney 1950, 12.

${ }^{22}$ Françoise Rigolot, "The Rhetoric of Presence: Art, Literature, and Illusion”, The Cambridge History of Literary Criticism, Vol. 3: The Renaissance, ed. Glyn P. Norton (Cambridge: Cambridge UP, 1999) 161-75, at 161 and 165.

${ }^{23}$ See Wesley Trimpi's illuminating discussion of Sidney's Defence, which argues against widespread assumptions - that Sidney rejects Neoplatonicideas and instead refers to an Aristotelian notion of mimesis in order to defend the ethical power of the poetic imitation of nature. Wesley Trimpi, "Sir Philip Sidney's An Apology for 
mere appearances, the visual aspect of this (moral) vision is of utmost importance, not only to the painter, but also to the poet: "Poesie ... is an art of imitation: ... a representing, counterfeiting, or figuring forth to speak Metaphorically. A speaking Picture". ${ }^{24}$ By this ability to create visual imagery and vivid impressions, Sidney further elaborates, the poet excels the philosopher, who can only describe ideals of behaviour, whereas "the speaking picture of Poesie" "yieldeth to the powers of the mind an image of that whereof the Philosopher bestoweth but a wordish description, which doth neither strike, pierce, nor possess the sight of the soul, so much as that other doth." 25

Notwithstanding his esteem for linguistically evoked vivid images, Sidney criticises the Elizabethan theatre for disregarding the Aristotelian unities and therefore relying too extensively on the power of words:

For it is faultie both in place and time, the two necessarie Companions of all corporal actions. For where the Stage should always represent but one place, and ... but one day; there is both manie dayes and places, inartificially imagined. ... [y] ou shall have Asia of the one side, and Affricke of the other, and so manie other under Kingdomes, that the Player when he comes in, must ever begin with telling where he is, or else the tale will not be conceived. Now you shall have three Ladies walke to gather flowers, and then we must beleeve the stage to be a garden. By and by we heare newes of shipwreck in the same place, then we are too blame if we accept it not for a Rock. ... while in the meane time two Armies fly in, represented with foure swords \& bucklers, and then what hard hart wil not receive it for a pitched field. ${ }^{26}$

Arguing against the frequent use of word scenery, Sidney demands the "commensurability of language and spectacle" on stage, ${ }^{27}$ or, in other words, the agreement of the verbal and non-verbal modes of theatrical semiosis. Purely verbal evocation should be reserved for 'reporting' rather than 'representing' on stage, according to Sidney: “Againe many things may be told which cannot be shewed: if they know the difference betwixt reporting and representing. As for example I may speake though I am here, of Peru, and in speech digresse from that, to the description of Calecut: But in action, I cannot represent it without Pacolets horse."28

As a reaction to Sidney's praise of poetry and his criticism of the theatre, Thomas Heywood in his Apology for Actors (1612) defended theatrical representation as the most appropriate form for truly creating speaking pictures.

Poetry", The Cambridge History of Literary Criticism, Vol. 3: The Renaissance, ed. Glyn P. Norton (Cambridge: Cambridge UP, 1999), 187-98, at 192-95.

${ }^{24}$ Sidney 1950, 11 (emphasis in the original).

${ }^{25}$ Sidney 1950, 17 and 16-17 (emphasis in the original).

${ }^{26}$ Sidney 1950, 42-43 (emphasis in the original).

27 Bluestone 1974, 39.

${ }^{28}$ Sidney 1950, 43 (emphasis in the original). 
In contrast to the rhetoric, which is, according to Heywood "only a shadow receiued by the eare but not perceiued by the eye" and to a picture, which "is meerely a forme seene by the eye, but can neither shew action, passion, motion, or any gesture, to mooue the spirits of the beholder to admiration", theatre unites all modes of perception, thus providing a synaesthetic experience. ${ }^{29}$ With reference to Ovid's story of Pygmalion, Heywood praises theatre as the art form which can awaken the images of poetry and painting to life. ${ }^{30}$

These contributions to the paragone are based, sometimes paradoxically, on both mimetic and idealistic assumptions. They presuppose that the art form excels whose semiosis comes closest, sensorily, to that of reality and can, morally, even improve reality by representing visions of, as Sidney puts it, 'what may be and should be.' Whereas they see mimetic art in the service of idealism, and hence of an ethical project, religiously motivated antitheatrical tracts such as Stephen Gosson's influential Playes Confuted in Fiue Actions (1582) in contrast emphasise the moral dangers inherent in verisimilitude. Theatre as a particularly skilful 'art of imitation', Gosson and others argue, might deceive spectators who take the action on stage for presentation rather than re-presentation and hence do not perceive the "lye" of actors employing "outwarde signes to shewe them selues otherwise than they are". ${ }^{31}$ William Prynne even argues that actors, using 'unlawful disguises', are transformed into beasts, among them asses - a complaint which is particularly interesting for the following discussion of A Midsummer Night's Dream. ${ }^{32}$

The antagonistic positions of Shakespeare's day open a spectrum which characterises discussions of theatrical semiosis until the present day. Shannon Jackson analyses such contradictory argumentative appropriations as what she calls the "flexible essentialism" of the theatrical semiosis:

Depending upon context, convenience, and polemics, theatricality can as easily find itself on the essentialist as anti-essentialist side of a conceptual binary.

${ }^{29}$ Thomas Heywood, An Apology for Actors, ed. Richard H. Perkinson (New York: Scholars' Facsimiles \& Reprints, 1941 [1612]) B3v. As Hagstrum points out, this competition between art forms is so pervasive in early modern society that it can be regarded as "one of the distinguishing marks of Renaissance thought". Hagstrum 1958, 66. Clark Hulse considers the discourse on the paragone even "universal - one might even say - unifying force within Renaissance aesthetics". Clark Hulse, The Rule of Art: Literature and Painting in the Renaissance (Chicago: $\mathrm{U}$ of Chicago P, 1990) 9.

${ }^{30}$ Heywood 1941 [1612], B3v.

31 Stephen Gosson, Plays Confuted in Fiue Actions (London 1582), E5r.

32 "For doe not all Actors [...] [put on] the portraitures and formes of [...] Asses [...], which in outward appearance metamorphose them into Idols, Devils, Monsters, Beasts, whose parts they represent? and can these disguises be lawfull, be tolerable among Christians? No verily." William Prynne, Histrio-Mastix: The Players Scourge; or, Actors Tragedie. London, 1633. 
Theatricality is used as a metaphor for representation and, in other contexts, as anti-representational ground for the authentic. ${ }^{33}$

Sidney's demand that the verbal and non-verbal modes of theatrical communication ought to conform draws on this understanding of theatre as an 'anti-representational ground for the authentic', which regards the divergence of the verbal and non-verbal theatrical channels of communication exclusively as a distortion, rather than also seeing in this gap a potential for fuelling the audience's imagination. This implicit assumption of verisimilitude as an ideal corresponds to the above-quoted research on Shakespeare's adaptation of the Metamorphoses, which presumes clear limits of the theatrical semiosis on the ground of its differences to the semiosis of the everyday. Paradoxically, it is Gosson's antitheatrical pamphlet which indicates that theatrical semiosis does not principally use mimetic or even 'natural' signs. Instead, it relies on signs which are always signs of signs. ${ }^{34}$ Uniquely among aesthetic forms, the theatre uses signs which can but do not necessarily have to be materially identical to their signified - thus, the body of an actor can signify the body of a character but it can also represent something else. Given this transferability, theatrical signs are highly mobile and hence potentially polyfunctional: ${ }^{35}$ Onstage, each object, each sound, each body can take on the meaning or the meanings with which it is attributed by its use through acting. Consequently, the theatre can resignify signs of the everyday. It is this theatrical power of resignification which is criticised and thereby spotlighted by the antitheatrical tracts in the Elizabethan era. The debate among Shakespeare's contemporaries about the moral and artistic status of the theatre and the "epistemology of spectatorship" 36 culminated in the discussion of a set of signs that was of particular importance beyond the stage and whose unambiguous signifying was of sociopolitical relevance: namely, costumes. In everyday life, the social function of dress - the demarcation of social belonging and gender - was endorsed by sumptuary laws which tried to control the privileges of the aristocracy in their uses of vestimentary codes. Both legislation and religious polemics against the dangerous use of theatrical costumes habitually referred to Deuteronomy to condemn cross-gender-dressing on and beyond the stage as a serious violation of the

${ }^{33}$ Shannon Jackson, "Theatricality's Proper Objects: Genealogies of Performance and Gender Theory", Theatricality, ed. Tracy C. Davis \& Thomas Postlewait (Cambridge: Cambridge UP, 2003) 186-213, at 189.

${ }^{34}$ See for example Erika Fischer-Lichte, Semiotik des Theaters: Das System der theatralischen Zeichen, Vol I (Tübingen: Narr, 1983), esp. 181-83 and Keir Elam, The Semiotics of Theatre and Drama, $2^{\text {nd }}$ ed., (London: Routledge, 2002).

${ }^{35}$ Fischer-Lichte 1983, 182-83.

36 Tracey Sedinger, “'If sight and shape be true': The Epistemology of Crossdressing on the London Stage", Shakespeare Quarterly 48.1 (1997): 63-79, at 63. 
semiotic system that was legitimised by God. ${ }^{37}$ The inefficacy of the sumptuary laws that attempted to suppress cross-class and cross-gender-dressing as well as the popularity of the theatre demonstrated forcefully, however, that the idea of a God-given, stable sign system was no longer fully tenable.

If we acknowledge the constitutive mobility and polyfunctionality of theatrical signs, there are principally no limits to 'what can and what cannot be done with bodies' on stage. Drawing on these preliminary thoughts on the semiotics of the theatre, I will in the following explore select moments of transformation in Titus Andronicus, The Winter's Tale and A Midsummer Night's Dream. The investigation of these metamorphoses will consider which modes of reverse ekphrasis, that is, which theatrical equivalents to narrated metamorphoses, were possible on the Elizabethan stage and how the aesthetics and conventions of other epochs and cultures have encountered this creative challenge.

\section{Titus Andronicus}

In Titus Andronicus Shakespeare explicitly refers to Ovid when Lavinia uses a book of the Metamorphoses to communicate the story of her rape and mutilation. ${ }^{38}$ When she points to Ovid's story of Philomela's violation, Titus

${ }^{37}$ Drawing on Deuteronomy 22:5, “The woman shall not wear that which pertaineth unto a man, neither shall a man put on a woman's garment: for all that do so are abomination unto the Lord thy God", Gosson calls clothes "[m]anifest signs of ... sex" "determined by the express rule of God". Gosson 1582, E3v. Cf. Jonas Barish, The Antitheatrical Prejudice (Berkeley and Los Angeles: U of California P, 1981) for an expansive discussion. See also Stephen Orgel, "Nobody's Perfect: Or, Why Did the English Stage take Boys for Women?" South Atlantic Quarterly 88.1 (1989): 7-29; Phyllis Rackin, "Androgyny, Mimesis and the Marriage of the Boy Heroine on the English Renaissance Stage", PMLA 102.1 (1987): 2941; Jean E. Howard, "Crossdressing, the Theatre and Gender Struggle in Early Modern England", Shakespeare Quarterly 39 (1988): 419-40 and "Power and Eros: Crossdressing in Dramatic Representation and Theatrical Practice", The Stage and Social Struggle in Early Modern England (London: Routledge, 1994), 93-128; Stephen Greenblatt, "Fiction and Friction", Shakespeare Negotiations: The Circulation of Social Energy in Renaissance England (Oxford: Clarendon Press, 1988), 66-93. See Cressy 1996 for an account of the historical facts beyond the assumption of a 'golden age of cross-dressing' as it is depicted in the romances and plays of the period: Although "[f]rom the 1570 s to the 1620 s, during the reigns of a manly queen and a queenish king, England is said to have been challenged by disorderly people presenting themselves in public in a gender-confusing manner," there are, according to Cressy, few historical records of cross-dressing at the time (451, 460). David Cressy, "Gender Trouble and Cross-Dressing in Early Modern England”, The Journal of British Studies, 35.4 (1996): 438-465.

${ }^{38}$ William Shakespeare, The Most Lamentable Tragedy of Titus Andronicus, The Norton Shakespeare, eds. Stephen Greenblatt et al. (London and New York: Nor- 
eventually realises that Chiron and Demetrius imitated and even surpassed the cruel proceedings of Tereus described by Ovid (4.1.56), since they severed not only Lavinia's tongue but also her hands to stop her from betraying them. Titus's brother Marcus, who first sees Lavinia after she escaped her torturers, acknowledges the relationship to Ovid at first sight: "A craftier Tereus, cousin, hast thou met, / And he hath cut those pretty fingers off / That could have better sewed than Philomel" (2.4.41-43). Accordingly, Titus models his revenge on Ovid's example, which he, like Lavinia's torturers, plans to exceed in cruelty: "For worse than Philomel you used my daughter, / And worse than Progne will I be revenged" (5.2.193-94). ${ }^{39}$ With reference to this selfreflexive adaptation of Philomel's story, Leonard Barkan demonstrates how Shakespeare's play gainfully connects the visual and verbal modes which theoreticians like Sidney and later Lessing sought to differentiate. ${ }^{40}$ In so doing, Barkan argues, the theatre also resolves the "competitive relations between the visual and the verbal" which coined the religious development from a pagan visual culture to the Christian emphasis on the holy Scripture:

Shakespeare need not have been aware of the jagged stepwise development of Ovidian text and picture from the end of the Middle Ages to see in his own time the Metamorphoses as a compendium of word and image. That is why Shakespeare can have Lavinia substitute Ovid's book for what was Philomela's tapestry. The Metamorphoses, especially in its Renaissance illustrated form, is a tapestry. That framed tapestry, with its inset perspective illustration and its Ovidian caption underneath, is also a model and a competitor for the problems

ton, 1997) 371-434, at 4.1.41-43. The following references in parentheses refer to this edition.

${ }^{39}$ Feminist readings have linked Titus's view of his daughter's violation as an injury of himself to the patriarchal logic which turns virginity and chastity into politically relevant concepts. See for example Coppélia Kahn, Roman Shakespeare: Warriors, Wounds, and Women (London and New York: Routledge, 1997) 71-72.

${ }^{40}$ As his ancient and early modern forerunners, Lessing in Laocoön: An Essay on the Limits of Painting and Poetry attempted to identify the characteristics of each art form and to develop a normative poetics on this basis. The difference between dynamics and stasis is crucial for his endeavour to distinguish literary and visual imagery. Lessing distances himself from the neoclassic formula of 'ut pictura poesis' and defines the visual arts as a spatial art as opposed to poetry as a temporal art. As Murray Krieger points out, Lessing does not revise the ideal of mimesis, since he demands the transparency of the medium itself: "jeder Zug, jede Verbindung mehrerer Züge, durch die uns der Dichter seinen Gegenstand so sinnlich macht, daß wir uns dieses Gegenstandes deutlicher bewußt werden, als seiner Worte, heißt malerisch, heißt ein Gemälde, weil es uns dem Grade der Illusion näher bringt, dessen das materielle Gemälde besonders fähig ist”. Gotthold Ephraim Lessing, Laokoon oder über die Grenzen der Malerei und Poesie (1766; Stuttgart: Reclam, 1987) 111. Krieger comments: "This suppression of the medium and with it all consciousness of the artistic process, seeks to turn arbitrary signs despite themselves - into the illusion of natural signs." Krieger 1992, 47. 
of dramatic representation, a kind of blueprint for theatre more apposite than words or pictures themselves. ${ }^{41}$

The fact that theatre generally relies on the interaction of visual and verbal modes can be highlighted not only by investigating this amalgamation of tapestry and book, but also by taking a closer look at the course of scene 2.4, in which Lavinia's body is interpreted, and thus rhetorically moulded, through speech acts.

When Marcus presents Lavinia to her father, both men emphasise to which degree Lavinia is already transformed by the mutilation: Titus hardly recognises his daughter ("But who comes with our brother Marcus here?" 3.1.58), and Marcus stresses, "This was thy daughter" (3.1.62, my emphasis). When Marcus first sees Lavinia in the previous scene, he responds, to the amazement and irritation of modern theatre practitioners and academic critics alike, with an extensive description of her mutilated body and employs decorous imagery including standard comparisons of Petrarchan love poetry. Academic research has offered manifold explanations for the stark contrast between the described and the description, between the cruel sight and the embellished rhetoric: Does Marcus in this way, as Mary Laughlin Fawcett argues, foreground the usually hidden morbid fascination of Petrarchan love poetry? ${ }^{42}$ Does the monologue demonstrate how women are turned into objects of desire and exchange by male rhetoric, as Coppélia Kahn proposes? ${ }^{43}$ Does it even amount to a second, verbal rape of Lavinia? ${ }^{44}$ Does the scene reveal how euphemistic Marcus's metaphors are, "by measuring their falseness against the irrefutable realities of dramatised events" ? 45 Or does it, on the contrary, trust in the healing power of poetry, "as though poetry is the scar that forms over a wound", as Alexander Leggatt suggests? ${ }^{46}$ Does the focus on Lavinia's separate body parts increase her suffering so much that the character becomes a representative of an abstract emotional state? ${ }^{47}$ Does the body of Lavinia metaphorically crit-

${ }^{41}$ Barkan 1986, 247.

42 "[Thus, the reader is] drawn too close to images whose main power has always been their nearness to death, but which we have conveniently elided into conventional compliments to beauty, trying to forget the connection between sexual satisfaction and death." Mary Laughlin Fawcett, "Arms/Words/Tears: Language and the Body in Titus Andronicus”, ELH 50 (1983): 261-77, at 273.

${ }^{43}$ Kahn 1997, 58-59.

${ }^{44}$ Mariangela Tempera, Feasting with Centaurs: Titus Andronicus from Stage to Text (Bologna: Cooperativa Libraria Universitaria Editrice Bologna, 1999) 157, 160.

45 Albert H. Tricomi, "The Aesthetics of Mutilation in 'Titus Andronicus'”, Shakespeare Survey 27 (1974): 11-19, at 13.

${ }^{46}$ Alexander Leggatt, Shakespeare's Tragedies: Violation and Identity (Cambridge: Cambridge UP, 2005) 18.

${ }^{47}$ Eugene M. Waith, “The Metamorphosis of Violence in Titus Andronicus”, Shakespeare Survey 10 (1957): 39-49, at 42-43. 
icise Elizabethan political imagery based on ancient stories? ${ }^{48}$ Or are the scene and its "bundle of ill-matched conceits held together by sticky sentimentalism" a burlesquing of contemporary style, as John Dover Wilson posits? ${ }^{49}$

In the context of Shakespeare's adaptation of Ovid's Metamorphoses, I would like to add yet another reading of this contrast between depicted violence and its poetic description. In his speech and his later encounter with Titus, Marcus envisions, in a metaphoric manner, the possibility of a redeeming Ovidian metamorphosis, in which a human being is merged with nature. ${ }^{50}$ Thus, he calls Lavinia's arms "branches" (2.4.18), the blood running from her mouth "crimson river" (2.4.22) and "bubbling fountain" (2.4.23), and compares her cheeks to the sun ("red as Titan's face", 2.4.31). In his memory, her tongue was a "sweet melodious bird" (3.1.85) and her hands "lily hands" (2.4.44), which could play a flute like trembling "aspen leaves" (2.4.45). Titus likewise de-humanises his daughter when he compares her tears to "honey-dew / Upon a gathered lily almost witheréd" (3.1.112-13). With reference to Ovid's story of Philomela's rape, mutilation and eventual transformation into a bird, I would argue that Titus and Marcus here evoke through verbal imagery the potential metamorphosis of Lavinia. As the objective of this transformation, they envision an abundance of possibilities, as if desperately giving cues to the merciless gods: a tree, a river, a fountain, a bird, a flower.

By suggesting such a transformation through linguistic comparison, Shakespeare equals Ovid's first step in the model story of Tereus and Philomela, in which Philomela is compared to a lamb and a dove:

illa tremit velutagna pavens, quae saucia cani

Ore axcussa lupi nondum sibi tuta videtur, utque columba suo madefactis sanguine plumis

horret adhuc avidosque timet, quibus haeserat, ungues. ${ }^{51}$

She quaketh like the wounded lambe which, from the wolve's hore teeth New shaken, thinkes hir selfe not safe; or as the dove that see'th

${ }^{48}$ Heather James, Shakespeare's Troy: Drama, Politics, and the Translation of Empire (Cambridge: Cambridge UP, 1997) 48.

49 John Dover Wilson, "Introduction”, William Shakespeare, Titus Andronicus (The New Shakespeare), ed. John Dover Wilson (Cambridge: Cambridge UP, 1948) i-lxxii, at liii-Iiv.

${ }^{50}$ In different contexts, some critics have likewise linked Marcus' monologue to Ovid. See James 1997, 64-65 for a similar reading of the monologue as a combination of Petrarchan imagery and references to Ovidian Metamorphoses such as that of Arethusa (into a river) and Byblis (into fountains). See Michael Hattaway for an interpretation of the monologue as an attempt to recreate the violent imagery of Ovid's rape description. Michael Hattaway, Elizabethan Popular Theatre: Plays in Performance (London: Routledge and Kegan Paul, 1982), at 200.

${ }^{51}$ Ovid 2003, 220. 
Hir fethers with hir owne bloud staynde, who, shuddring still, doth feare

The greedie hauke that did hir late with griping talents teare. ${ }^{52}$

Likewise, in a second step, Ovid's story suggests that the subjective gaze of the observers initiates the transformation: "Corpora Cecropidum pennis pendere putares: / pendebant pennis." 53 Here, Golding emphasises the importance of the observer's position more strongly than the Latin original: "He that had bene present would have deemde / Their bodies to have hovered up with fethers. As they seemde, / So hovered they with wings in deede." 54 Audiences of Titus Andronicus may expect as a third step the same incarnation of the comparison and the same realisation of the observer's imagination (that is, the bodily transformation of Lavinia into a bird, river, lily, or aspen) - in particular because throughout Titus Andronicus, figurative language is transformed into events and, in turn, particular events are recalled through figurative speech. As Albert H. Tricomi has shown, "the most profound impulse in Titus is to make the word become flesh". ${ }^{55}$ However, Titus Andronicus, according to the genre expectations of a tragedy, stops short at the imagined transformation of Lavinia. She cannot escape from her sad state like Philomela and Procne, who turn into nightingales; instead, she remains a "map of woe" (3.2.12) which Titus, Marcus and Lucius attempt to read and, once deciphered, use as instruction for their revenge before ultimately destroying it. In Titus Andronicus, the linguistic evocation of a physical, supernatural metamorphosis hence does not offer release from bodily pain. By contrast, the divergence of the verbal and the visual makes Lavinia's suffering more palpable and heightens the alertness for Lavinia's already transformed body. ${ }^{56}$

This already transformed body, like many other instances of extreme violence in the play, poses a challenge for stage productions of Titus Andronicus: Does Lavinia's mutilation have to be visualised, as the notorious stage direction at the beginning of 2.4 indicates, "Enter the Empress' sons with Lavinia, her hands cut off and her tongue cut out, and ravished"? And if a company decides to do so, how can this be achieved? Although the surviving evidence of how the play and this scene were staged during Shakespeare's day is meagre (apart from recorded performance dates), ${ }^{57}$ and, as Dennis Kennedy

52 Golding 2005, 46.

${ }^{53}$ Ovid 2003, 228.

${ }^{54}$ Golding 2005, 50.

55 Tricomi 1974,14. Cf. also his analysis of the reciprocal process: "Constantly pointing toward and underlining the events that we witness upon the stage, metaphor in this tragedy strains to keep the excruciating images of mutilation ever before our imaginations even when the visual spectacle is no longer before us." (12).

${ }^{56}$ Cf. D. J. Palmer, "The Unspeakable in Pursuit of the Uneatable: Language and Action in 'Titus Andronicus”, Critical Quarterly 14.4 (1972): 320-29, at 321.

57 The first performance probably took place in 1589-90 and the play was first published in 1594; the play was popular on the Elizabethan stage and was revived in 
points out in his seminal study Looking at Shakespeare: A Visual History of Twentieth-Century Performance "[o]nce Shakespeare's own theatrical codes [i.e., the visuals encoded in language] were no longer readable (even in London this happened by 1660), our ability to read this visual assumption had also been seriously affected," 58 it is safe to say that the monologue probably served a double function on the non-representational Elizabethan and Jacobean stages: Firstly, it evoked or at least reinforced Lavinia's bodily transformation, since her mutilation was not, or at least not fully, shown visually. The maximal visualisation of physical wounds was probably produced by sponges filled with vinegar that were concealed under the actors' armpits; in special cases, calves' and sheep's blood was possibly also used. ${ }^{59}$ Secondly, I would argue, the monologue verbally created the image of a subsequent, redeeming metamorphosis.

The post-Restoration stage history of Titus Andronicus differs from most of the other Shakespeare plays, since it is characterised by a long period of neglect. The extreme violence of the play, as well as its reputation as a flawed piece of writing, resulted in the fact that after the considerable success of Titus Andronicus until the early Restoration, the first major professional production of the play without significant alterations did not take place until 1923, under the direction of Robert Atkins at the Old Vic. ${ }^{60}$ In modern stagings, the first function of the monologue is often obsolete, since Lavinia's injuries are usually visually represented, albeit with varying theatrical devices. Twentieth and twenty-first century productions have tended to follow one of three general possibilities in their visualisation of violence in general and Lavinia's mutilation in particular, as Alan C. Dessen has amply shown in his resourceful book on Titus Andronicus in performance: First, they stage the action, and in particular the scenes of violence, in a formalised, non-realistic manner. Second, they attempt to stage the play and its violence realistically, which suggests for Lavinia's mutilation the use of artificial blood, the concealing of

Jacobean times. For a brief account of the stage history of the play, see G. Harold Metz, "Stage History of Titus Andronicus", Shakespeare Quarterly 28 (1977): 154-69. Alan C. Dessen offers a more extended version: Alan C. Dessen, Shakespeare in Performance: Titus Andronicus (Manchester, New York: Manchester UP, 1989) 7-12.

${ }^{58}$ Dennis Kennedy, Looking at Shakespeare: A Visual History of Twentieth-Century Performance, $2^{\text {nd }}$ ed. (Cambridge: Cambridge UP) 13.

${ }_{59}$ Andrew Gurr, The Shakespearean Stage 1574-1642, $3^{\text {rd }}$ ed. (Cambridge: Cambridge UP, 1992) 182-84.

${ }^{60}$ Michael Cordner, “'Are We Being Theatrical Yet?’: Actors, Editors, and the Possibilities of Dialogue", A Companion to Shakespeare and Performance, eds. Barbara Hodgdon \& W.B. Worthen (Oxford: Blackwell, 2005) 399-414, at 400. For a concise discussion of adaptations of Titus on the Continent and the British stage after the Renaissance, see Jonathan Bate, "Introduction”, Titus Andronicus, ed. Jonathan Bate (London: Routledge, 1995) 1-121, at 48-59 and, in particular on Edward Ravenscroft's influential 1678 revision, Dessen 1989, 7-12. 
the actress's hands and the attachment of (bloodied) stumps to her arms or clothes. Third, they emphasise the grotesque features and thus treat the play as a parody. ${ }^{61}$

The most famous representative of the first, stylised approach is Peter Brook's 1955 RSC staging, which was, as the first modern Stratford-uponAvon production of Titus Andronicus, so unexpectedly successful that Dessen considers the opening night "the second birthday" ${ }^{2}$ for the play script. In scene 2.4, Vivien Leigh playing Lavinia entered to the slow plucking of harpstrings, which were amplified by a microphone and reminded reviewers of the sound of blood dripping; white and scarlet streamers representing her wounds were attached to her wrists and mouth (cf. illustrations 1 and 2). ${ }^{63} \mathrm{~A}$ number of productions followed Brook's non-realistic approach to the scene. Some varied his visual solution, for example by using red rhinestone drops to indicate the blood running from Lavinia's stumps or by a vertical red line across Lavinia's lips that stood for the mutilation of her mouth, while others took up Brook's device of red ribbons, among them Gerald Freedman's 1967 production for the New York Shakespeare Festival ${ }^{64}$ and the recent production by the Japanese director Yukio Ninagawa, shown in Stratford in 2006. While Brook's production, according to the director's view of the play as "the expression of a powerful and eventually beautiful barbaric ritual", ${ }^{65}$ presented Lavinia in stylised, contained, almost elegant poses, with flawless make-up and intact clothing, in Ninagawa's staging, her white dress was dirtied and torn, her hair undone, and her gestures and facial expression expressed her desperation (cf. illustrations 3 and 4). Employing principally the same visual device as Brook, Ninagawa's production hence nonetheless abstained from an aesthetic containment of rape and violence and emphasised Lavinia's pain by a psychologically more expressive way of acting.

The most acclaimed examples of the second option, a verisimilar approach to the scene, were offered by two later RSC productions, directed by Trevor Nunn in 1972 and by Deborah Warner in 1987 (cf. illustrations 5 and 6). The latter, highly influential, realisation intended, as Warner emphasised in interviews, "to hurt" and to "find ways of making it [the rape] unbearable ... [,] of making the audience scream out they could not take any more" ${ }^{66}$ As Kennedy notes, Warner's production fulfilled this mission, "to judge by

\footnotetext{
${ }^{61}$ Dessen 1989, 24.

${ }^{62}$ Dessen 1989, 15.

${ }^{63}$ Cf. Jack E. Reese, "The Formalization of Horror in Titus Andronicus", Shakespeare Quarterly 21 (1970): 77-84, Kennedy 2001, 170 and Bate 1995, 59.

${ }^{64}$ Cf. Dessen 1989, 24-33 and Mentz 1977, 165-66 for discussions of Freedman's and other productions that formalised the atrocities.

${ }^{65}$ Peter Brook, The Empty Space, $3^{\text {rd }}$ ed., (1968; London: Penguin, 1990) 106, emphasis mine.

${ }^{66}$ Warner in an interview with Kennedy. Kennedy 2001, 338.
} 


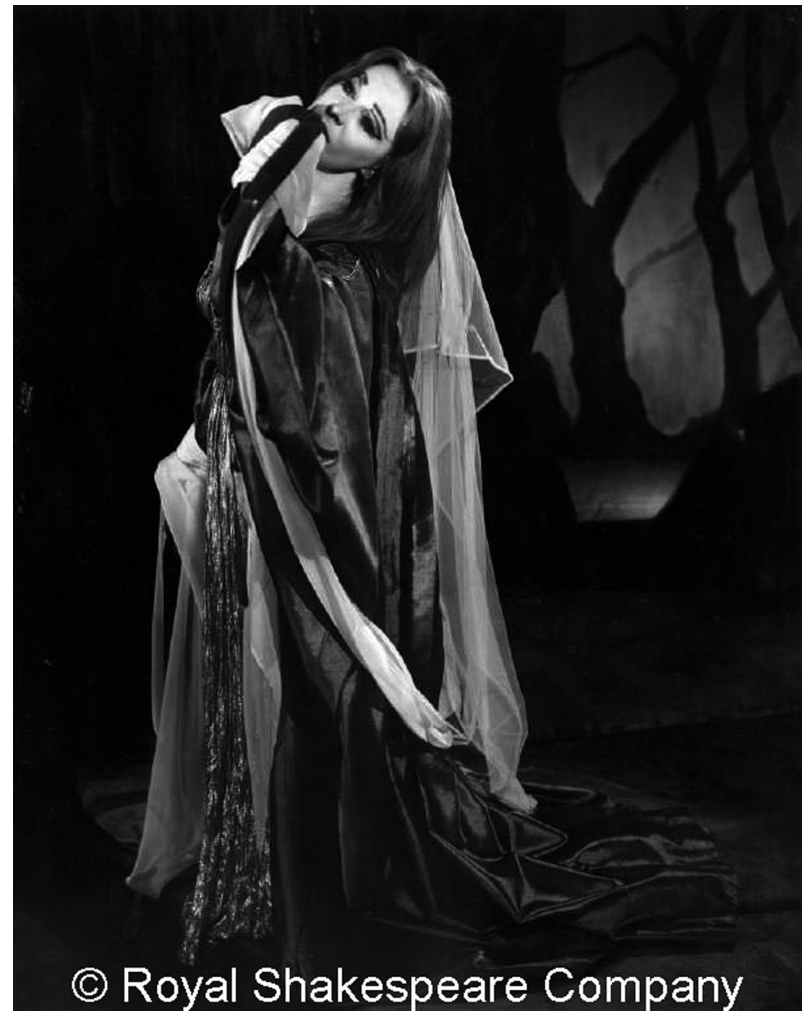

Figure 1: Peter Brook, 1955 (1)

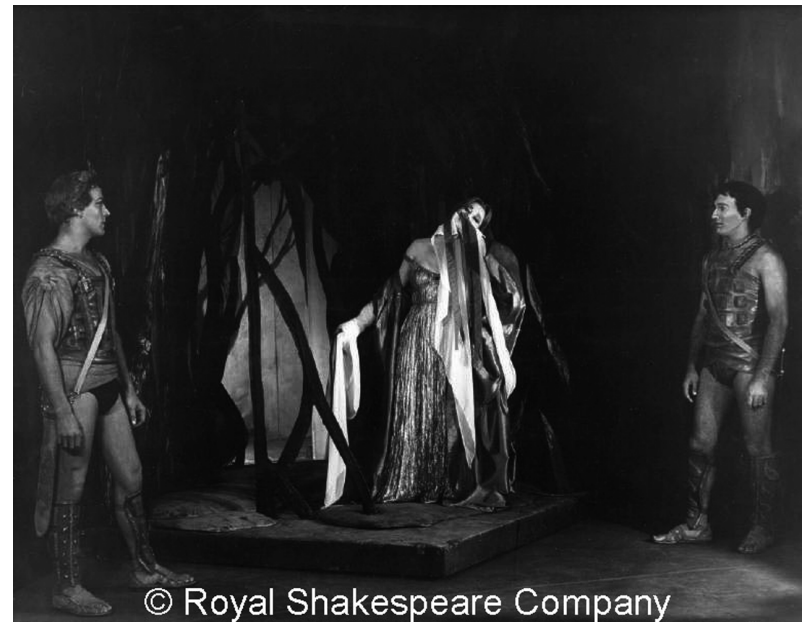

Figure 2: Peter Brook, 1955 (2) 


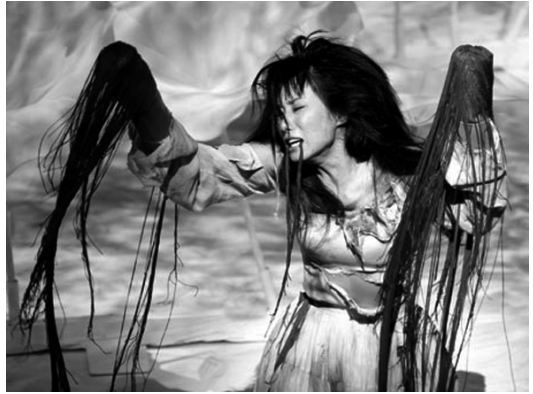

Figure 3: Yukio Ninagawa, 2006 (1)

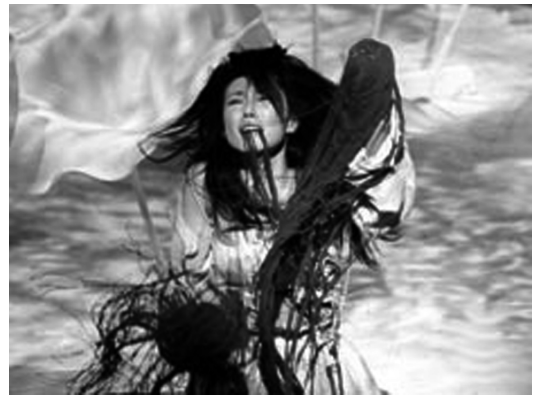

Figure 4: Yukio Ninagawa, 2006 (2)

the faintings and heart failures her spectators sometimes suffered". ${ }^{67}$ To visualise Lavinia's mutilated body in scene 2.4, Warner's production attached wrapped stumps to the arms of Sonia Ritter playing Lavinia, had her clothing encrusted by mud reminiscent of blood, and blood trickle from her mouth. Reviewers additionally praised Ritter's expressive body language, which emphasised the pain and shame involved in every of Lavinia's movements.

Just as stage realisations of the scene have varied in their visual depiction of Lavinia, so have they differed in their treatment of her verbal portrayal by Marcus. Whereas for the Elizabethan non-representational stage aesthetics, the detailed description of Lavinia's bodily mutilation was vital to induce or at least buttress her injuries, in the 1857 adaptation of the play by C.A. Somerset and Ira Aldridge, the rape victim could for reasons of taste not be shown on stage at all. ${ }^{68}$ As stagings since 1923 illustrate, Marcus's highly rhetorical, 47-line-monologue seems an unlikely and disturbing response to the sight of his injured niece to modern sensibilities that are shaped by a "post-Elizabethan sense of emotional or psychological truth" and that are used to a different theatrical aesthetics. ${ }^{69}$ Therefore, while the sight of the rape victim is once again possible on stage, her verbal description is still a delicate issue: "Whilst no longer unstageable, the scene was still thought to be unspeakable", as Bate points out. ${ }^{70}$ Consequently, stage realisations have most often shortened or fully deleted Marcus's monologue. Of the productions already discussed, Brook's cut the speech and even Marcus's entry entirely and instead presented Lavinia's stylised apparition as a silent tableau. In Nunn's staging, the monologue was shortened by 18 lines, including the

\footnotetext{
${ }^{67}$ Kennedy 2001, 338.

${ }^{68}$ Cf. "A Review of Ira Aldridge's Titus at the Britannia, Huxton [1857]", Titus Andronicus: Critical Essays, ed. Philip C. Kolin (New York and London: Garland, 1995) 377-78; Dessen 1989, 11-12; Bate 1995, 58-59.

${ }^{69}$ Dessen 1989, 57.

${ }^{70}$ Bate $1995,59$.
} 


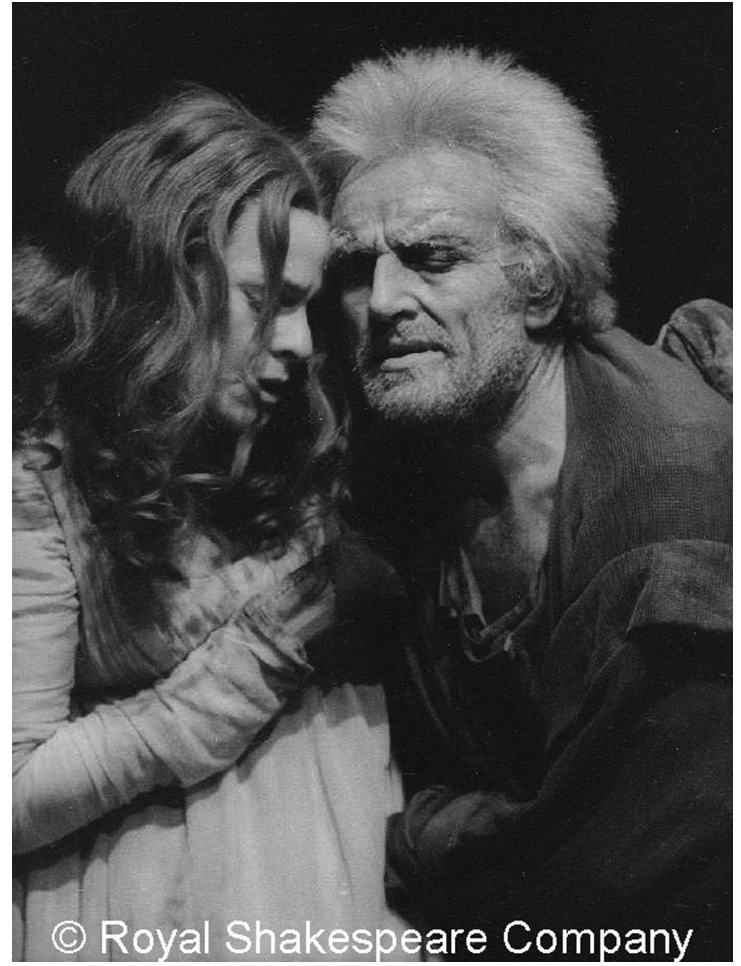

Figure 5: Trevor Nunn, 1972

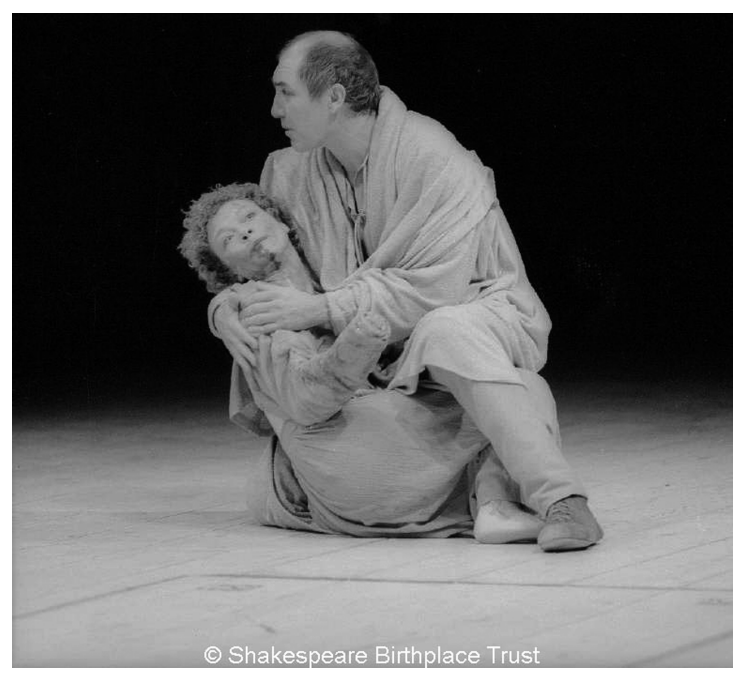

Figure 6: Deborah Warner, 1987 
rhetorical comparisons of Lavinia's body. ${ }^{71}$ Exceptionally, Warner's staging presented the entire speech, ${ }^{72}$ which inspired a number of critics to re-assess the function of the monologue and to acknowledge that the verbal imagery can lead to a productive interaction with the visual imagery: Audiences see Lavinia's body both by themselves and through Marcus's images and can thereby gain insight into Marcus's attempt to come to terms with the devastating sight. ${ }^{73}$

The enactment of the entire monologue onstage additionally, as I have argued above, introduces the idea of the second, supernatural metamorphosis of Lavinia. While no theatrical production, to the best of my knowledge, as yet has chosen to visualise Marcus's metaphors and similes, some productions have employed stage images which represented the second bodily metamorphosis in a deficient, non-redeeming form and hence reinforced the gap between the actual sight and the mental vision. For example, Sonia Ritter's body language in Warner's production gains an additional meaning when audiences simultaneously expect or at least hope for Lavinia's mythical transformation into a nightingale: As Dessen notes, Ritter played Lavinia "as a drab, crawling subhuman creature, caked with clay, characterised by intermittent, jerky movements" which reminded him "of a wounded bird". ${ }^{74}$ This dehumanised figure that is unable to move properly is a distressing, incapacitated version of the Ovidian nightingale and of Marcus's 'sweet melodious bird'. Correspondingly, in Julie Taymor's 1994 stage and 1999 film version of Titus Andronicus, Lavinia's torturers attach broken twigs to her stumps and place her on a truncated column where she stands motionless during the first part of Marcus's speech, thus cruelly anticipating his imagery of Lavinia as a tree. ${ }^{75}$ Taymor here takes up Brook's less explicit iconography, in which

${ }^{71}$ Bate 1995, 59-60; Dessen 1989, 54.

72 As Dessen notes, the only modern production which also included the entire speech before Warner's staging was performed during the Colorado Shakespeare Festival in 1967. Alan C. Dessen, "Titus Andronicus [at the RSC, Stratford-upon-Avon, 1988]", Titus Andronicus: Critical Essays, ed. Philip C. Kolin (New York/London: Garland, 1995) 453-57, at 454.

${ }^{73}$ Dessen 1989, 60.

${ }^{74}$ Dessen 1989, 66.

${ }^{75}$ Cf. Julie Taymor's documentation of her stage production, directed at New York's Theatre for a New Audience in 1994, in Eileen Blumenthal and Julie Taymor, Playing with Fire: Theater, Opera, Film (New York: Harry N. Abrams, 1995), 182201. For a discussion of trauma aesthetics and the differences between Taymor's film version and her earlier stage version, see David McCandless, "A Tale of Two Tituses: Julie Taymor's Vision on Stage and Screen”, Shakespeare Quarterly 53.4 (2002): 487-511. For a treatment of the elements of horror and the abject in Taymor's stage and film version, see Lisa S. Starks, "Powers of Horror in Julie Taymor's Titus", The Reel Shakespeare: Alternative Cinema and Theory, ed. Lisa S. Starks \& Courtney Lehmann (London: Associated UP, 2002), 121-42. 


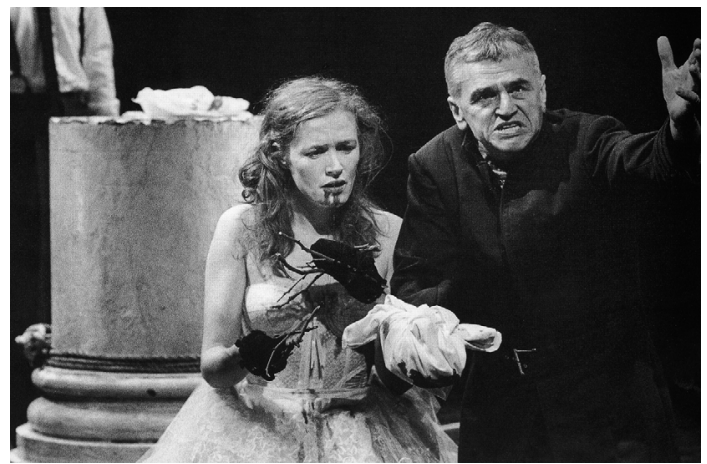

Figure 7: Julie Taymor, 1994 (1)

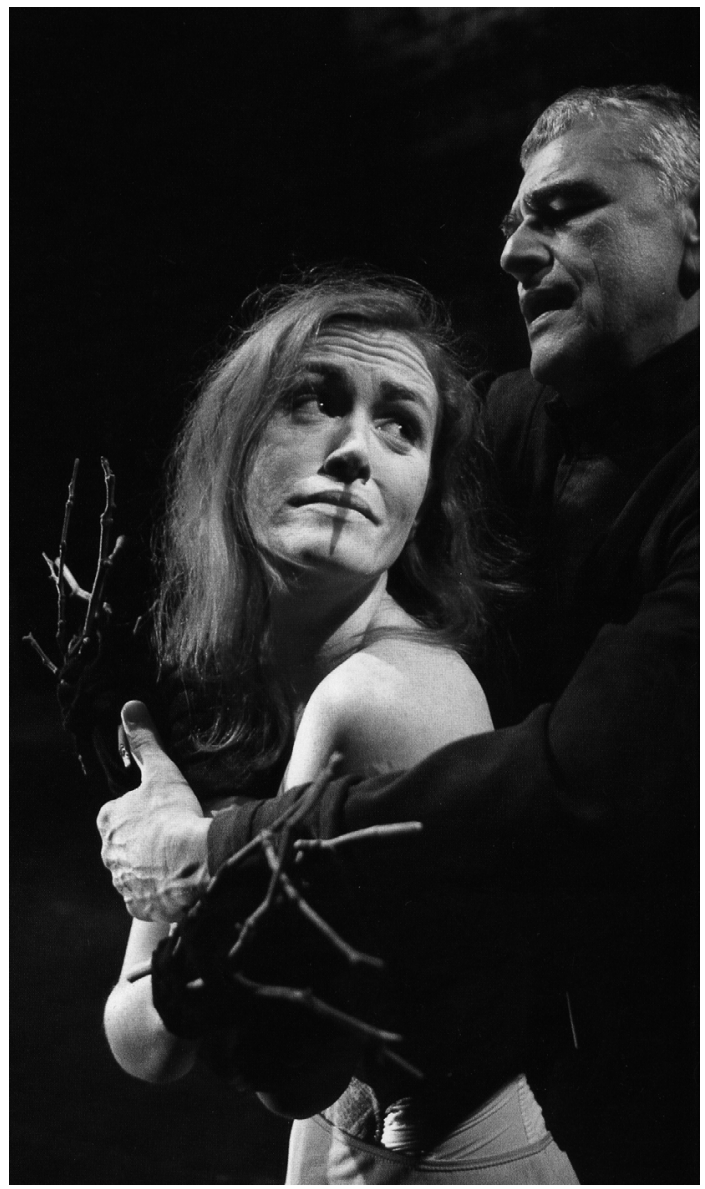

Figure 8: Julie Taymor, 1994 (2) 


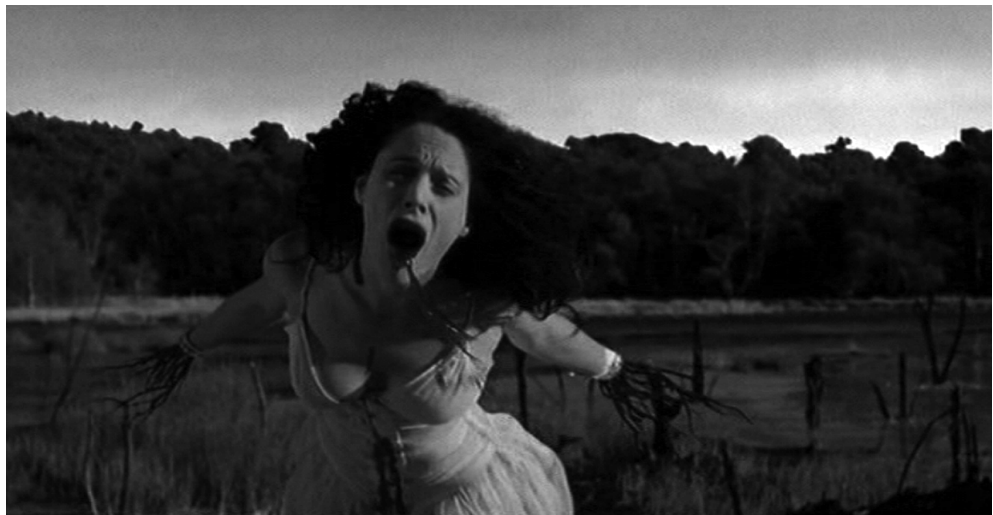

Figure 9: Julie Taymor, 1999 (1)

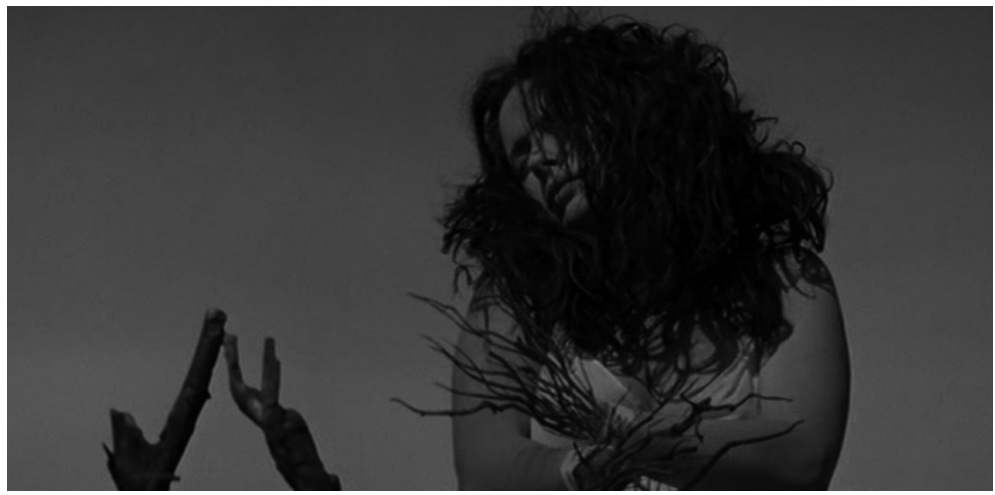

Figure 10: Julie Taymor, 1999 (2)

the ribbons streaming from Lavinia's wounds resemble the tree branches of the scenery in the background (cf. illustrations 7, 8, 9, 10 and 2).

By verbally and, in some productions, also visually, evoking but eventually withholding Lavinia's redeeming metamorphosis by divine intervention, the scene thus reinforces the awareness of the characters on stage, but also of audiences, for the brutality of Lavinia's bodily mutilation by human hands. This setting up of simultaneous, contradictory imagery supports and qualifies the received opinion that Lavinia represents "the starkest portrayal of a nonmetamorphosed, mutilated body in the entire Shakespeare canon". ${ }^{76}$ The withholding of the metamorphosis is even more effective, I would argue, since the play does not rely only on the audience's knowledge of Ovid's

${ }^{76}$ Burrow 2002, 307. 
model story, but creates through Marcus's speech the counter-images of the transformed Lavinia which will make audiences hope for a process of reverse ekphrasis, of the word made flesh. Hence, despite the fact that Kenneth Tyran saw Brook as "the prophet of an unborn time, when to show images will be more than to tell phrases" 77 , the scene demonstrates powerfully that on stage, the visual and the verbal modes do not have to cancel each other out, but that their co-existence and, more than that, their interaction and divergence, are potent theatrical devices that engender a complex play with the idea of bodily transformations.

\section{The WinteR's TAle}

In comparison to the verbal evocation of a supernatural metamorphosis in Titus Andronicus, The Winter's Tale goes a step further regarding the interaction of verbal and non-verbal modes on stage: To stage the illusion of a metamorphosis, the reanimation of Hermione's statue combines the verbal evocation of a metamorphosis with visual signs, thus granting speech and imaginative perception the performative power which it is denied in Titus. In The Winter's Tale, Shakespeare extends and enhances his main source, Robert Greene's Pandosto (1588), through references to a number of myths, including those recounted in Ovid's Metamorphoses. After the first three acts in which the queen, as in Greene's romance, dies after her husband has imprisoned her and publicly accused her of adultery, the action is replete with mythical allusions derived from the Metamorphoses. For example, as A. D. Nuttall has shown, it implicitly refers to the myth of Orpheus and Eurydice and explicitly to that of Proserpina. ${ }^{78}$ The mythical reference that is most relevant for my analysis of media transformation is the one to Ovid's Pygmalion story. Throughout acts one to three, the play reverses the story in

77 Qtd in Kennedy 2001, 172.

${ }^{78}$ A. D. Nuttall, “The Winter's Tale: Ovid Transformed”, Shakespeare's Ovid: The Metamorphoses in the Plays and Poems, ed. A.B. Taylor (Cambridge: Cambridge UP, 2000) 135-49. Cf. also Jane M. Miller, "Some Versions of Pygmalion”, Ovid Renewed: Ovidian Influences on Literature and Art from the Middle Ages to the Twentieth Century, ed. Charles Martindale (Cambridge: Cambridge UP, 1988) 205-14. Potential alternative and additional sources are Asclepius of the Corpus Hermeticum, the myth of Alcestis and Euripides' play Alcestis, Francis Sarbie's The Fisherman's Tale and the Amadis de Gaule romances. See Stephan Laqué, "'Lawful as Eating' - Mythos und Regeneration in The Winter's Tale", Shakespeare Jahrbuch: Shakespeare als Erzähler von Märchen und Mythen, eds. Ina Schabert et al. (Bochum: Kamp, 2006) 60-77, at 75; Raphael Lyne, Shakespeare's Late Work (Oxford: Oxford UP, 2007) 41; Martin Mueller, “Hermione’s Wrinkles, or, Ovid Transformed: An Essay on The Winter's Tale", Comparative Drama 5.3 (1971): 226-39; E. A. J. Honigmann, "Secondary Sources of The Winter's Tale", Philological Quarterly 34.1 (1955): 27-38. 
a metaphorical manner by showing how Hermione is petrified by Leonte's jealousy and hate. ${ }^{79}$ Hermione's petrifaction does not only mean a restriction of her agency, it also offers her - with the assistance of Paulina - a space of safe retreat and ultimately, in her appearance as a statue, a means to even intensify Leontes's grief and repentance and to fulfil the women's lesson against misogyny. In this respect, The Winter's Tale cannot be regarded only as a variation of the Pygmalion story, but also as its continuation, as T.G. Bishop proposes: "Hers [Hermione's] is the gesture of Galatea discovering - at some later date - the misogyny and distrust of (female) sexuality which led Pygmalion to carve and love her in the first place." 80 The ending of the play stages Hermione's depetrification and reanimation, which unexpectedly rewards Leontes for decades of grief and repentance. Since the restorative reunion of king and queen depart from the tragic ending of Pandosto, in which the queen remains dead and the king, due to his incestuous desire for his daughter, commits suicide, the surprise and wonder at the reanimation on the part of audiences in Shakespeare's day was probably greater than nowadays, when Greene's tragic romance is much lesser known than Shakespeare's by now famous plot.

Before audiences (both on and offstage) can see the statue, however, Paulina prepares and thus influences their visual perception through verbal announcements. For instance, she declares that the true-to-life look of the statue is due to the exceptional ability of her creator: "Prepare to see the life as lively mocked as ever / Still sleep mocked death" (5.3.18-20). ${ }^{81}$ In bringing up the issue of art imitating nature, the scene offers a spectacular culmination of the prior debates between Perdita and Florizel regarding a paragone between life and art. ${ }^{82}$ Paulina's show demonstrates (albeit preliminarily) how art can excel in this paragone ("life as lively mocked"), drawing on the tenth book of the Metamorphoses, in which the narrative voice likewise emphasises the life-like appearance of Pygmalion's statue: “virginis est verae facies, quam

${ }^{79}$ Vgl. Bate 1993, 236. While Hermione's petrifaction by Leontes's hate can be regarded as an inversion of the Pygmalion story, Klaus Reichert emphasizes parallels between the stories, since Leontes creates an unfaithful wife through words just as Pygmalion constructs a companion from ivory. Klaus Reichert, "Die Wirklichkeit des Eingebildeten oder Kunst und Trick", Pygmalion: Die Geschichte des Mythos in der abendländischen Kultur, eds. Mathias Mayer \& Gerhard Neumann (Freiburg: Rombach, 1997) 497-516, at 500.

${ }^{80}$ T.G. Bishop, Shakespeare and the Theatre of Wonder (Cambridge: Cambridge UP 1996) 162.

${ }^{81}$ William Shakespeare, The Winter's Tale, The Norton Shakespeare, eds. Stephen Greenblatt et al. (London and New York: Norton, 1997) 2837-954. The following references in parentheses refer to this edition.

${ }^{82}$ Cf. Hagstrum $1958,81-88$ on the competition between art and nature in the Renaissance. 
vivere credas ... : ars adeo latet arte sua". ${ }^{83}$ Golding's translation resolves the paradoxical formula "ars adeo latet arte sua", "to such a degree art concealed its art", and does not insist on the naturalness of utmost art: "The looke of it was ryght a maiden's looke, / And such a one as that yee would beleeve had lyfe ... / So artificiall was the work." 84 While this reference to Ovid befits Paulina's project, other allusions have to be varied or withheld to persuade on- and off-stage spectators of the artificiality of Hermione's appearance: For instance, Paulina prevents Perdita and Leontes from kissing the statue and thus from imitating Pygmalion: "the colour's / Not dry" (5.3.47-48), "The ruddiness upon her lip is wet" (5.3.81). The argument that the human, adoring spectators could soil themselves underpins Paulina's project of emphasising the lifelessness of the statue and reverses the concern portrayed by Ovid that the statue could be stained by too intensive contact: "et metuit, pressos veniat ne livor in artus". ${ }^{85}$ Golding translates the sentence, literally meaning 'and fears that blue colour (bruises) could come in the touched body parts' more ambivalently: "He ... feared lest sum blacke or broonsed print / Should come by touching over hard." ${ }^{86}$ In his version, it is already unclear whether the caresser or the caressed is in danger of being marked.

When Paulina eventually promises to animate the statue, quasi-performative speech acts are particularly relevant. ${ }^{87}$ Thus, Leontes is ready to believe in Hermione's resurrection after Paulina's warning, "No longer shall you gaze on't, lest your fancy / may think anon it moves." (5.3.60-61). Leontes remarks, "Would you not deem it breathed, and that those veins / Did verily bear blood?" (5.3.63-64) and "Still methinks / There is an air comes from her" (5.3.77-78). The creative power of speech comes even more to the fore when Hermione moves after Paulina's order, “Tis time. Descend. Be stone

${ }^{83}$ Ovid 2003, 272. Cf. Pauline Kiernan's reading of Paulina's announcement, which argues that it is replete with irony, thus foreshadowing that art ultimately cannot excel nature, as well as her illuminating discussion of the debate between Polixenes and Perdita, in which, to her eyes, Perdita emerges as victor: "Perdita exposes the absurdity of art which arrogantly attempts to imitate, perfect and surpass nature". Pauline Kiernan, Shakespeare's Theory of Drama (Cambridge: Cambridge UP, 1996) 68-72 and 77-83, at 81.

${ }^{84}$ Golding 2005, 87, 11.268-71.

${ }^{85}$ Ovid 2003, 272.

${ }^{86}$ Golding 2005, 87, 11.277-79.

${ }^{87}$ Lynn Enterline shows that in earlier scenes performative speech acts hardly ever work: "In The Winter's Tale, oath-taking and swearing faith take on the particular (Ovidian) futility, since neither utterances aspiring to state the truth nor words conventionally designated as actions exercise any force." Enterline rightly points out that Paulina's enunciations are not performative utterances in the strict linguistic sense, but display "an idea about language as performance ... : the dream of a voice so persuasive that it can effect the changes of which it speaks." Lynn Enterline, The Rhetoric of Body from Ovid to Shakespeare (Cambridge: Cambridge UP, 2000) 214 and 222. 
no more. Approach" (5.3.99), and when Leontes discerns the movement of his wife after Paulina's suggestion, "You perceive the stirs" (5.3.104). As in Ovid's model story of Pygmalion, Leontes now touches the ostensible statue, feels her warmth and eventually hears her speak. By this gradual perception of the spectators both on and off stage, which focuses on one sense after the other (seeing, touching, hearing), Shakespeare stages Ovid's stepwise animation of Pygmalion's statue and thus shows that a theatrical adaptation of bodily metamorphosis must not, as Harzer argues, remain a freeze image:

Ut rediit, simulacra suae petit ile puellae

incumbensque toro dedit oscula: visa tepere est.

admovet os iterum, manibus quoque pectora temptat:

temptatum mollescit ebur positoque rigore

subdidit digitis creditque, ...

corpus erat! Saliunt temptatae pollice venae. ...

dataque oscula virgo

sensit et erubuit timidumque ad lumina lumen

attolens pariter cum caeleo vidit amantem. ${ }^{88}$

As onne [sic] as he came home, streyghtway Pygmalion did repayre

Unto the image of his wench, and, leaning on the bed

Did kisse hir. In her body streyght a warmeness seemd to spred.

He put his mouth againe to hers and on her brest did lay

His hand. The ivory wexed soft, and putting quyght away

All hardnesse, yeelded underneathe his fingars ...

He felt it verrye flesh in deede. By laying on his thumb,

He felt her pulses beating. ...

She felt the kisse and blush therat, and lifting fearefully

Hir eyelidds up, hir lover and the light at once did spye. ${ }^{89}$

In contrast to Ovid's erotic scene of animation, Paulina, well aware of the destructive and petrifying, rather than animating, potential of Leontes' voyeurism and jealous sexual passion, stages the awakening as a ritual which strictly controls Leontes's access to (the statue of) his wife. ${ }^{90}$

For theatrical realisations of the resurrection, the scene offers two principal ways of staging: It can either create dramatic irony by informing audi-

${ }^{88}$ Ovid 2003, 274.

${ }^{89}$ Golding 2005, 88, 11.305-20.

${ }^{90}$ Cf. Joel Davis's discussion of the play and Pandosto in comparison to both Ovid's Pygmalion story and the story of Orpheus and Eurydice; Davis traces the voyeurism inherent in the three texts which present the female body as "an object made desirable by the interplay between accessibility and inaccessibility". Joel Davis, "Paulina's Paint and the Dialectic of Masculine Desire in the Metamorphoses, Pandosto, and The Winter's Tale", Papers on Language and Literature 39.2 (2003): 115-43, at 119. 
ences about the playacting of Hermione, for example by having her enter the stage and assuming the pose of the statue in front of the audience but hidden from the onstage spectators, or they can attempt to stage the awakening in a more illusionist manner, which most productions opt for. This second option demands an extended period of motionless standing from the actress, which some productions have facilitated by placing her with the back to the audience (thus making audiences focus on the reactions of the bystanders), by having her lean on pedestals, or by placing her in a mirrored box as in Trevor Nunn's 1969 RSC staging. ${ }^{91}$ From the early modern period, no account of the resurrection scene has survived; Simon Forman's notes on the 1611 performance he saw at the Globe playhouse does not provide any information about the staging; from later performances, such as at King James's court in November 1611 and further performances between 1612 and 1634, no evidence about the theatrical realisation of the scene has survived either. As Dennis Bartholomeusz' performance history of The Winter's Tale and Stephen Orgel's discussions of the play richly illustrate, since the eighteenth century, the resurrection scene was increasingly presented as the emotional hinge of the play and became so popular that it was even played out of context, as prelude or coda to another play. ${ }^{92}$ In addition to the challenge of presenting a motionless figure, stage realisations have to decide what the statue should look like - for example, how old and how realistic it should look, and which kind of statue would have been most apt for Paulina's gallery. While the dialogue makes clear that the statue is painted and looks remarkably realistic, unlike conventional Elizabethan tomb statues and unlike the remains of ancient Greek statues, ${ }^{93}$ William Charles Macready's productions between 1823 and 1843 at Drury Lane and Covent Garden heightened the surprise of Hermione's awakening by presenting her, as a reviewer remarked in 1833 , as an antique statue with an "apparel like marble."94

Another question is how saintly the statue should look - in this regard, productions since the eighteenth century have often enhanced the scene's sense of wonder by allusions to Christian iconography. For instance, in the popular adaptation Florizel and Perdita, which focused on the romantic aspects of Shakespeare's play and played down its tragic side, directed by David Garrick at the Drury Lane and playing throughout the 1750s and 1760s (and revived in the 1770s), Mrs Pritchard as Hermione was dressed in a similar way to iconographic representations of Saint Mary and even wore a neck-

\footnotetext{
${ }^{91}$ Dennis Bartholomeusz, The Winter's Tale in Performance in England and America 1611-1976 (Cambridge: Cambridge UP, 1982), 210-21.

92 Bartholomeusz 1982, Stephen Orgel, Imagining Shakespeare: A History of Texts and Visions (Basingstoke and New York: Palgrave Macmillan, 2003) 127-28 and Stephen Orgel, "Introduction”, The Winter's Tale, ed. Stephen Orgel (Oxford: Clarendon, 1996) 1-83, at 62-77.

${ }^{93}$ Bartholomeusz 1982, 25.

${ }^{94}$ Qtd in Bartholomeusz 1982, 72.
} 
lace with a large cross - it thus opted for a Catholic bias in its interpretation of the play's debatable magic, religious and liturgical significances..$^{95}$ Similarly, Trevor Nunn and John Barton's RSC production in 1976 presented the statue "half-turned towards the audience and caught in blue and light white, ... spiritual, like the Blessed Virgin". ${ }^{96}$ Other productions emphasised the sense of wonder without suggesting a Christian religious background, such as the 1802 production at the Drury Lane Theatre, directed by John Philip Keble: It had rays of light emerge from the statue, which resembled a Grecian muse. ${ }^{97}$

A common psychological device ever since a production in 1887 at the Lyceum is the doubling of the roles of Perdita and Hermione, which offers a way to visualise their alikeness and, at the same time, mitigates Leontes's incestuous desire for Perdita by presenting it as displaced desire for his lost wife. For the resurrection scene, this device poses a complication, since Hermione and Perdita are onstage together here for the only time; usually the actress of Perdita is replaced for this scene.

Notwithstanding individual staging decisions, the scene gains an additional appeal in performance through its metatheatrical awareness of the oscillating gaze of audiences, of the simultaneity of perception in the theatre which involves both "[o]ur scepticism and our pleasure at the pretense of the theatrical". ${ }^{88}$ When Paulina after the resurrection declares, "That she is living, / Were it but told you, should be hooted at / Like an old tale. But it appears she lives" (5.3.117-19), the play maintains that the theatre emerges as the victor in the paragone of the arts. Shakespeare here replaces the supernatural metamorphosis of Ovid's narrative by self-aware and self-confident theatricality, ${ }^{99}$ which employs both aspects of the flexible theatrical essentialism. On the one hand, it creates verisimilitude, as in the exemplary productions discussed above, and thus aims at a "crass deception of the audience [that] is unique in Shakespeare." 100 On the other hand, it acknowledges the discrepancy between reality and dramatic representation when Paulina, the director of the resurrection show, asks the characters on stage (and with them, the

${ }_{95}$ Bartholomeusz 1982, 35-37. For discussions of the debatable religious stance of the play that critics have derived from Paulina's demand of faith, the presentation of the statue in a chapel, the music that accompanies the ceremony and the idea of transubstantiation, see for example S. L. Bethell, The Winter's Tale: A Study (1947); Darryll Grantley, “The Winter's Tale and Early Religious Drama”, Comparative Drama 20.1 (1986): 17-37; Alice Daily, "Easter Scenes from an Unholy Tomb: Christian Parody in The Widow's Tears", Marian Moments in Early Modern British Drama, eds. Regina Buccola \& Lisa Hopkins (Aldershot: Ashgate, 2001), 127-39, at 133-5; Orgel 1996, 59-62.

${ }_{96}$ Bartholomeusz 1982, 224.

${ }^{97}$ Bartholomeusz 1982, 61.

${ }_{98}$ Bishop 1996, 170.

${ }^{99}$ Vgl. Burrow 2002, 310.

${ }^{100}$ Mueller 1971, 227. 
audience offstage) not only for a suspension of disbelief, but even for their 'faith': 101 "It is required / You do awake your faith" (5.3.94-95). ${ }^{102}$ In this metatheatrical comment, Paulina invites audiences to direct their oscillating gaze away from the business of performing (a male actor plays a female character who plays a statue) to the performed business (depending on the previous knowledge of the plot, the animation of a statue or the playacting of Hermione).

The scene's play with perception and, in particular, with the double perception typical of theatrical reception, can offer a "tremendous influx of self-conscious excitement" even for audiences who are already familiar with the plot of The Winter's Tale and expect Hermione's resurrection. ${ }^{103}$ In this context, Nevill Coghill has argued that the naming of a real-life artist, Giulio Romano, as originator of the statue, as well as the sheer length of the scene, during which the actress playing Hermione has to keep motionless, might contribute to the persuasion of adept audiences "against hope" that Hermione is dead and the figure on stage a statue. ${ }^{104}$ Bishop hence identifies the contradictory phenomena that lead to a sense of wonder in the resurrection scene: “the sense of inhabiting a borderline 'between' knowledge and emotion, of a fearful power both in and beyond the spectator, an acute self-consciousness of the medium". ${ }^{105}$ Additionally, a second element of surprise is decisive, namely the audience's potential realisation that they wish Hermione "fervently back into life". ${ }^{106}$ Thus, through presenting a case of ostensible physical metamorphosis, the scene stages the transformation of the viewing habits and the emotional involvement of those who witness this metamorphosis, both on and off stage. ${ }^{107}$

${ }_{101}$ Vgl. Bate 1993, 237.

${ }^{102}$ Robert Egan emphasises that this plea is even more effective because audiences have seen in the earlier scenes of The Winter's Tale that lack of faith can have fatal effects: "Lack of faith ... is the central destructive force in the play's world". Drama within Drama: Shakespeare's Sense of His Art in King Lear, The Winter's Tale, and The Tempest (New York: Columbia UP, 1975) 66.

103 Bishop 1996, 170. Cf. also Anthony B. Dawson and Paul Yachnin, The Culture of Playgoing in Shakespeare's England: A Collaborative Debate (Cambridge: Cambridge UP, 2001) 105: "The mixture of theatrical and meta-theatrical effects generates an affective and participatory pleasure.... It involves both understanding and imaginative projection .... Most important ..., however, it is the interplay between the pleasures that derive from the actors' presence, and the audience's awareness of the actors as representation."

${ }^{104}$ Nevill Coghill, "Six Points of Stage-Craft in The Winter's Tale", Shakespeare Survey 11 (1969): 31-41, at 40.

${ }^{105}$ Bishop 1996, 167.

106 Bishop 1996, 169.

107 See also Mary Ellen Lamb, “Ovid and The Winter's Tale: Conflicting Views toward Art", Shakespeare and the Dramatic Tradition. Special Issue of Studies in 
This self-confident presentation of theatre's capacity to create simultaneously intellectual self-reflexivity and emotional involvement contributes to the paragone of Shakespeare's day, in particular to its moral and religious dimension. Before Heywood's above-cited eulogy and Shakespeare's The Winter's Tale, William Gager likewise employed the Pygmalion myth to demonstrate the representative power of the theatre, albeit in order to heavily criticise it. Through an analogy to Pygmalion's statue, Gager diagnoses the danger of an erotic temptation through the boy actors, "[f]or men may be ravished with love of stones, of dead stuffe, framed by cunning gravers to beautiful womens likenes, as in Poets fables appeareth by Pygmalion." 108 Like Gosson, Gager discounts the ability of audiences to differentiate between the performed business and the business of performing; instead of allowing for a complex notion of art (and reality) as proposed in The Winter's Tale, he presumes the complete deception of audiences. ${ }^{109}$ The celebration of the representative quality of the theatre in The Winter's Tale opposes such an understanding of theatre as ground of the mimetic or authentic. Shakespeare here and throughout his plays promotes, in Pauline Kiernan's terms, dramatic illusion, that is, "the self-proclaimed fiction which paradoxically explores realities and compels belief", rather than endorsing the mimetic illusion celebrated in theoretical writings and works of art in the 1590s and 1600s. ${ }^{110}$ That such a mimetic notion of theatrical performance can even be dangerous is illustrated at the beginning of The Winter's Tale, when Leontes ignores the conventions of courtly behaviour and takes Hermione's friendliness towards Polixenes at face value, as proof of her love. ${ }^{111} \mathrm{~A}$ misunderstanding of performance as ground of the authentic, beyond courtly/theatrical conventions, is also criticised in my final example, A Midsummer Night's Dream. Here, the play-within-the-play of the mechanics parodies the naive notion of theatre as a merely mimetic medium. By showing how a play should not be staged and not be perceived, the scenes offer audiences, ex negativo, a complex notion of theatrical representation. ${ }^{112}$

English Literature 1500-1900, eds. W. R. Elton \& William B. Long (Newark: U of Delaware P, 1989) 69-87, at 72.

108 William Gager, The Overthrow of Stage Playes (London, ca. 1599) E3v. Lamb shows that also the author of the Pygmalion story was attacked by the enemies of the stage. Ovid served as epitome of the unmoral poet, after whose model Elizabethan poets, and in particular dramatists, should be banished. Lamb 1989, 73-74.

109 Cf. also Lamb 1989, 81.

${ }^{110}$ Kiernan 1996, 3 and passim.

111 Cf. also Lamb 1989, 91.

112 Cf. Louis Montrose, The Purpose of Playing: Shakespeare and the Cultural Politics of the Elizabethan Theatre (Chicago: U of Chicago P, 1996) 191; Gary Jay Williams, Our Moonlight Revels: A Midsummer Night's Dream in the Theatre (Iowa: U of Iowa P, 1997) 21 and Kiernan 1996, 108-16. 


\section{A Midsummer Night's Dream}

A Midsummer Night's Dream alludes to a multitude of mythical metamorphoses, such as the story of Pyramus and Thisbe, which is mirrored not only in the play-within-the-play of the artisans but also in the relationship of Lysander and Hermia. Robin is introduced as a character resembling Ovid's gods, who not only have the power to transform others but can also themselves shift shapes. My following brief analysis will focus on Bottom's transformation into an ass, which is modelled on Lucius Apuleius' Asinus Aureus but corresponds to the transformations of human beings into animals as described by Ovid - as the subtitle of the story, Metamorphoses, already indicates. In A Midsummer Night's Dream, Bottom's visual transformation works via synecdoche. As Robin comments, “[a]n ass's nole [is] fixed on his head". ${ }^{113}$ An aesthetics of synecdoche was typical of the Elizabethan stage, which indicated settings through merely partial scenery and props and enhanced them by speech and playacting. As characteristic of this "theatre ... of percepts supported by words" 114 , language and acting also reinforce the extent of Bottom's transformation. It is part of the play's comic effect that through the utterances of the characters, four different extents of transformation evolve: Whereas Bottom does not realise that his shape has shifted, the other artisans react to his transformation with surprise and fear and comment on how thoroughly he has changed in their eyes. Yet, Snout's "O Bottom, thou art changed. What do I see on thee?" (3.1.102) shows that he still recognises Bottom and sees something (the head) 'on him'. Hence, the transformation is only partial in the eyes of the artisans. In contrast to their fear and repulsion, the spellbound Titania, "enthrallèd" by Bottom's "beautiful" (3.1.131) "shape" (3.1.123), falls in love with Bottom who, in her perspective, is a "gentle mortal" (3.1.121). Robin, when he reports to Oberon, calls Bottom a "monster" (3.2.6) and emphasises that Titania fell in love with "an ass" (3.2.34); and so does Titania, once cured from her love ("Methought I was enamoured of an ass" 4.1.73). These comments make clear that the ass's head works for both Robin and Titania as a pars-pro-toto transformation.

Audiences are in the intermediate position to witness all these different perceptions. However, every stage realisation will make some of the percep-

${ }^{113}$ William Shakespeare, A Midsummer Night's Dream, The Norton Shakespeare, eds. Stephen Greenblatt et al. (London and New York: Norton, 1997) 805-64, at 3.2.17. The following references in parentheses refer to this edition. This moment of putting on the ass's head happens off stage and hence cannot be witnessed by audiences. That this ellipsis of the actual moment of transformation remains a Leerstelle, a gap which has to be filled in by the recipient's imagination, is also a not uncommon device in Ovid's stories, for example in the story of Narcissus. Cf. Ovid 2003, 142 and Golding 2002, 111, 11. 641-42.

${ }^{114}$ Bluestone 1974, 55-56. 
tions more and some less comprehensible - how frightening does the ass's head look? How realistic should it be? Should Bottom be more fully transformed? Is the head necessary at all? The Folio stage direction "Enter Puck, and Piramus with ass-head on" probably documents the first staging of the play in the 1590s, and the oldest surviving report of an early modern staging of A Midsummer Night's Dream in 1631 documents that the actor of Bottom "did in ... a brutishe manner acte" "attyred with his asse head, and a bottle of hay sett before him". ${ }^{115}$ British Victorian productions maintained this synecdochic staging but heightened its realism by using elaborate ass heads with working ears and mouths. ${ }^{116}$ In twentieth- and twenty-first-century productions, the sexual appeal associated with the ass was frequently emphasised. The stagings thus not only highlight another mythical origin of the play, namely Pasiphaë's lust for a bull, whose product, the Minotaur, was killed by Theseus before the onset of the play's action, ${ }^{117}$ but also offer an explanation for Titania's attraction beyond the magic juice. For example, Bill Alexander's 1986 RSC staging stripped off Bottom's shirt and provided him with a fur balaclava with ears, ${ }^{118}$ and in Jürgen Gosch's recent production at the Deutsches Theater in Berlin, which premiered in 2007, Bottom was entirely undressed and carried a huge, branching bough reminiscent of a deer head, first covering his crotch, and later his forehead. Alternatively, modern productions did without props, thus paying tribute to the play's emphasis on the subjectivity of perception. In Robert Lepage's 1992 production at the National Theatre in London, for instance, the actress playing Robin coiled her legs around Bottom's neck, with her feet sticking out, resembling ass's ears. ${ }^{119}$ As these few examples of staging options indicate, heterogeneous signs can be employed to depict Bottom's physical transformation on stage. All of them, however, rely on the audience's ability and willingness to participate in this semiosis, or, in Bottom's own words, to 'see an ass-head of [their] own'.

Due to their intermediate position, audiences cannot only appreciate the comic dramatic irony that derives from Bottom's precise and yet ignorant figures of speech, "This is to make an ass of me" (3.1.106), "I am such a tender ass" (4.1.23-24), "What do you see? You see an ass-head of your own, do you?" (3.1.103-04), but they can also gather their metatheatrical relevance: The latter comment in particular calls attention to the fact that Bottom's metamorphosis is the product not only of props and costume, but also of the audience's imagination and their willingness to participate in the staged fic-

\footnotetext{
115 Qtd in Trevor W. Griffiths, Shakespeare in Production: A Midsummer Night's Dream (Cambridge: Cambridge UP, 1996) 9.

116 Cf. Griffiths 1996, 146.

117 Cf. Orgel 2003, 92.

118 Griffiths 1996, 146.

119 Ibid.
} 
tion - an imagination which is fuelled by comments such as Quince's "Thou art translated" (3.1.105), as well as Bottom's desire to eat hay and dried peas once he is transformed. A Midsummer Night's Dream famously parallels this emphasis on the creative power of the gaze in its depiction of a series of magic transformations carried out by Robin which manipulate the sensory perception and emotions of the young lovers and of Titania. By demonstrating the imaginative force of love which creates realities, these magical transformations literalise the metaphor of blind love. By showing how quickly love can change, however, the play also demonstrates how provisional and constructive the perspective of a lover is. When Hermia says, "Methinks I see these things with parted eye, / When everything seems double." (4.1.186-87), she acknowledges this imaginative 'seeing-as', this oscillating gaze of the lover who sees doubly: She perceives love as a product of imagination, and hence as fallible, but at the same time and for this very reason as precious and 'true'. ${ }^{120}$ Hence, the gaze of the lovers resembles the gaze of theatre spectators, who willingly can allow the action on stage to transform their sensory perception and emotional state. In Robin's famous epilogue, he comments on this parallel between theatre audiences and the enchanted lovers, when he calls the performance "but a dream" (6) in which the spectators saw "shadows" (1) and "visions" (4). In another metatheatrical comment, the play, like The Winter's Tale, reflexively relates this interaction between verbal and non-verbal modes, as well as between stage and audience, to the act of creation by the author in Theseus's famous statement: "And as imagination bodies forth / The forms of things unknown, the poet's pen / Turns them to shapes, and gives to airy nothing / A local habitation and a name. Such tricks hath strong imagination / That ... in the night, imagining some fear / How easy is a bush supposed to be a bear!" (5.1.14-22). Due to the polyfunctionality of theatrical signs, a bush can stand for a bear and an actor wearing an ass's head - or, when it comes to more modern stagings of A Midsummer Night's Dream, no head at all - stand for an ass, as long as characters on stage treat them like this and as long as audiences participate in this semiosis.

These brief analyses of select moments of metamorphosis in Shakespeare's dramatic adaptation of Ovid have explored three principal theatrical strategies for staging transformations which have engendered a variety of stage realisations through the centuries: (1) a purely linguistic evocation of bodily change in the tragedy of Titus Andronicus, which opposes and hence reinforces the visually and linguistically created sign, the mutilated body, (2) the interaction of linguistic and physical transformation in The Winter's Tale and (3) a synecdochic visual transformation which is reinforced verbally in A Midsummer Night's Dream. The metatheatrical comments of the plays

${ }^{120}$ Verena Olejniczak Lobsien and Eckhard Lobsien, Die unsichtbare Imagination: Literarisches Denken im 16. Jahrhundert (München: Fink, 2003) 154. 
indicate that Shakespeare's theatre was as self-aware as it was self-confident of its medial and aesthetic specifities and the creativity that was needed to stage transformations. Shakespeare's 'artistic manifesto' is thus implied in the plays, ${ }^{121}$ be it through references to the paragone or the address of audiences through forms of mise en abyme, as shown, for instance, by Paulina's resurrection and the performance of the artisans. As this manifesto confirms, the requirement that audiences must leave behind the semiosis of the everyday in favour of theatrical semiosis is not understood as a deficiency or 'limit' of the theatre, as Bate argues: "in that forgetting [that we are in the theatre], we come as near as is humanly possible to a witnessing of metamorphosis". ${ }^{122}$ On the contrary, the co-existence of both forms of semiosis, the artistic and the everyday, offers an additional appeal. The simultaneous perception of the performed business and the business of performing means that audiences witness not only the innerfictional metamorphoses, but also the incessant metamorphoses of theatrical signs, including the bodies of actors, which constitute and distinguish theatre as an art form.

Augsburg

Christina Wald

${ }^{121}$ Egan 1975, 89. 